To cite this article: Kocyigit BF, Koca TT. Neuropathic pain adversely affects functional status, quality of life and depression in patients with knee osteoarthritis. Ortadogu Tıp Derg 2019; 1: 15-21.

\title{
Neuropathic pain adversely affects functional status, quality of life and depression in patients with knee osteoarthritis
}

\section{Nöropatik ağrı diz osteoartritli hastalarda fonksiyonel durumu, yaşam kalitesini ve depresyonu olumsuz etkiler}

\author{
Burhan Fatih Koçyiğit*@ Tuba Tulay Koca
}

Kahramanmaras Sutcu Imam University Faculty of Medicine, Department of Physical Medicine and Rehabilitation, Kahramanmaras/Turkey

\begin{abstract}
Aim: The aim of our study was to determine the existence of neuropathic pain (NP) in knee OA and its association with risk factors, functional status, quality of life, and depression.

Material and Methods: This was a descriptive study. A total of 100 patients ( 90 female, 10 male) with knee OA were enrolled. Data including age, gender, educational status, working status, body mass index, and symptom duration were obtained from patients. Patients were divided into three groups according to the PainDETECT scores: likely NP, possible NP, unlikely NP. Patients' pain severity was assessed using visual analogue scale (VAS). For the presence of NP, PainDETECT scale was used. Functional status was evaluated by Western Ontario and McMaster University Osteoarthritis Index (WOMAC). Quality of life was assessed using Short Form-36 questionnaire (SF-36) and depression level was evaluated using Hamilton Depression Scale (HAM-D). Kellgren-Lawrence grading system was used to determine the radiologic severity. Pain, functional status, quality of life and depression were compared among the groups.
\end{abstract}

Results: Of the total, 18 patients (18\%) were in the likely NP group; 23 patients (23\%) were in the possible NP group and 59 (59\%) patients were in the unlikely NP group. No significant differences were detected between the groups in sociodemographic data ( $p>0.05$ ). Significant differences were detected in symptom duration, VAS, WOMAC, SF-36 physical functioning subscale, physical role functioning subscale, social role functioning subscale, vitality subscale, bodily pain subscale, general health perceptions subscale and HAM-D scores among the groups $(p<0.05)$. PainDETECT scores were significantly correlated with VAS, WOMAC, SF-36 subscales, and HAM-D $(p<0.05)$.

Conclusion: This study revealed that NP is associated with severe pain, reduced functionality, impairment in quality of life, and higher depression scores in patients with knee OA.

Keywords: knee osteoarthritis; neuropathic pain; functional status; quality of life; depression

Corresponding author*: Burhan Fatih Koçyiğit, Kahramanmaraş Sütçü İmam University Faculty of Medicine, Department of Physical Medicine and Rehabilitation, Kahramanmaraş/Turkey

E-mail: bfk2701@hotmail.com

ORCID: 0000-0002-6065-8002

Received: 20.06.2018 Accepted : 16.09.2018

Doi: 10.21601/ortadogutipdergisi.435075 


\section{Öz}

Amaç: Çalışmamızın amacı, diz OA'da nöropatik ağrı (NA) varlığını ve risk faktörleri, fonksiyonel durum, yaşam kalitesi ve depresyon ile ilişkisini belirlemektir.

Gereç ve Yöntemler: Bu tanımlayıcı bir çalışmadır. Diz OA'i tanılı toplam 100 hasta (90 kadın, 10 erkek) çalışmaya alındı. Hastalardan yaş, cinsiyet, eğitim durumu, çalışma durumu, vücut kütle indeksi ve semptom süresini içeren veriler elde edildi. PainDETECT skorlarına göre hastalar üç gruba ayrıldı: pozitif NA, muhtemel NA, negatif NA. Hastaların ağıı şiddeti görsel analog skala (GAS) ile değerlendirildi. NA varlığı için PainDETECT ölçeği kullanıldı. Fonksiyonel durum Western Ontario ve McMaster Üniversitesi Osteoartrit Inndeksi (WOMAC) ile değerlendirildi. Yaşam kalitesi Kısa Form-36 anketi (KF-36), depresyon düzeyi Hamilton Depresyon Skalası (HAM-D) kullanılarak değerlendirildi. Radyolojik değerlendirme için Kellgren-Lawrence evreleme sistemi kullanıldı. Gruplar arasında ağrı, fonksiyonel durum, yaşam kalitesi ve depresyon karşılaştıııldı.

Bulgular: Toplam 18 hasta (\%18) pozitif NA grubunda, 23 hasta (\%23) muhtemel NA grubunda, 59 hasta negatif NA grubundaydı. Sosyodemografik verilerde gruplar arasında anlamlı fark saptanmadı ( $p>0.05$ ). Semptom süresi, GAS, WOMAC, KF-36 fiziksel fonksiyon alt ölçeği, fiziksel rol işleyişi alt ölçeği, sosyal fonksiyon alt ölçeği, canlılık alt ölçeği, ağrı alt ölçeği, genel sağlık durumu alt ölçeği ve HAM-D skorları arasında gruplar arasında anlamlı fark bulundu $(p<0.05)$. PainDETECT skorları GAS, WOMAC, KF-36 alt ölçekleri ve HAM-D ile anlamlı olarak koreleydi $(p<0.05)$.

Sonuç: Bu çalışma diz OA hastalarında NA'nın şiddetli ağrı, azalmış işlevsellik, yaşam kalitesinde bozulma ve daha yüksek depresyon skorları ile ilişkili olduğunu ortaya koymuştur.

Anahtar kelimeler: diz osteoartriti; nöropatik ağrl; fonksiyonel durum; yaşam kalitesi; depresyon

\section{Introduction}

Osteoarthritis $(\mathrm{OA})$ is a chronic disease characterized by progressive cartilage destruction, joint pain, limitation of movement and loss of function [1]. OA is one of the leading health problems of the aging population and cause of morbidity which seriously restricts daily life activities and social performance. Persistent symptoms of OA lead to decrease in working performance and increase in health care costs [2].

The most common symptom of $\mathrm{OA}$ is pain. The etiology and pathophysiology of pain in OA is not completely clear. Traditionally, pain associated with knee OA has been classified as nociceptive. However, nociceptive components cannot completely explain the symptoms such as hypersensitivity, referred pain and numbness [3]. Unlike the cartilage structure, subchondral bone has neural innervation. Besides cartilage structure synovium, subchondral bone and soft tissue participate in the mechanisms of pain in OA [4]. The nerve fibers in the knee which lead to neuropathic pain (NP) may get sensitized by ongoing inflammation or subchondral bone damage [5]. Perioperative samples of knee OA have neural impairments that may stimulate NP [6]. Peripheral and central sensitization play a prominent role generation of pain derived from joint $[7,8]$. Continuous and intensive nociceptive inputs from the osteoarthritic knee cause central sensitization. Central sensitization may contribute to the emergence of NPassociated clinical feature. All treatment choices have been aimed to decrease the pain level arising from osteoarthritis. Patients who dominantly have NP do not benefit from nonsteroidal anti-inflammatory drugs. Additionally, using drugs targeting NP has been found to improve symptomatic response in the knee OA [9].

Treatment choices of NP include differences from nociceptive pain. We consider that NP component in knee OA is overlooked by physicians. Therefore, primary aim of our study was to evaluate the existence of NP component in knee OA patients. Secondary aim was to assess the link between NP and functional capacity, quality of life, and depression.

\section{Material and Methods}

This was a descriptive study conducted between September 2017 and November 2017. A total of 128 OA patients who applied to our polyclinic were evaluated. After the application of the exclusion criteria, a total of 100 patients with knee 
OA were included in the study. All the patients included in this study met the American College of Rheumatology (ACR) criteria for knee OA. All the participants had knee pain for more than 3 months. Patients who had a history of knee surgery, infection, trauma, peripheral spondyloarthritis, rheumatoid arthritis, tumour, central nervous system disorder, peripheral nerve injury, radiculopathy, diabetes mellitus, vitamin B12 deficiency, polyneuropathy, drug use for neuropathy/NP were excluded from this study. Previous medical history (electromyogram, magnetic resonance imaging, tomography, and drugs) was evaluated using hospital database.

\section{Data sources and measurement}

Data including age, sex, educational status, working status, body mass index and symptom duration were obtained from patients.

The standing antero - posterior radiographs of the patients were evaluated by the same physician using the Kellgren-Lawrence grading system [10]. The radiographs were taken from the same device, technique, dose and distance. Grade 0 is defined as normal; grade 4 is defined as severe radiologic disease.

Visual Analog Scale (VAS) $(0 \mathrm{~cm}$ to $10 \mathrm{~cm})$ was performed to detect severity of pain ( 0 indicates no pain, 10 indicates the highest level of pain).

Western Ontario and McMaster Universities Osteoarthritis Index (WOMAC) is used to determine the functional level in knee OA. It includes 3 sections; pain, stiffness and physical function. Each question is scored from 0 to 4 , which makes the highest score 96. Increasing total scores indicate the worsening of functional status [11]. The Turkish reliability and validity studies were conducted [12].

The PainDETECT scale was initially developed to define NP component in patients with chronic low back pain. Additionally, PainDETECT was validated for the diagnosis of NP in patients with chronic pain. Maximum score of this scale is 38. Score between 0 and 12 is considered as unlikely NP, score between 13 and 18 is considered as possible NP and score between 19 and 38 is considered as likely NP. The Turkish version of the PainDETECT questionnaire was developed and validity and reliability studies were conducted [13, 14].

The Short Form-36 (SF-36) questionnaire contains 36 questions and 8 subscales (physical functioning, physical role functioning, social role functioning, vitality, emotional role functioning, bodily pain, general health perceptions and mental health) to evaluate quality of life. Maximum score of a subscale is 100. Higher scores indicate better quality of life. The Turkish reliability and validity study was conducted $[15,16]$

Hamilton depression scale (HAM-D) includes 17 questions to assess the depression level of patients. Cut-off value of this scale is 14. Higher scores indicate the worsening of depression level HAM-D was performed by the same physician. The Turkish reliability and validity study was conducted $[17,18]$.

\section{Ethical considerations}

Ethical approval was obtained from the Medical Ethics Committee and written informed consent was received from all subjects in accordance with the principles of the Declaration of Helsinki (Decision date: 16.08.2017; Decision number: 04).

\section{Statistical Analysis}

SPSS (Statistical Package for Social Sciences) version 20.0 for Windows (SPSS Inc., Chicago, IL, USA) was used for statistical analysis of the data. Shapiro-Wilk test was performed to assess the distribution of continuous variables. Mean value and standard deviation was used for continuous variables and median (minimum-maximum) for discrete variables. Linear regression analysis was performed to determine factors affecting painDETECT scores. Spearman rho test was performed for the correlation analyses. Comparisons of groups were evaluated with Kruskal-Wallis test and Chi-Square test. The statistical significance value was accepted as 0.05 .

\section{Results}

In this study, 100 knee OA patients (90 female, 10 male) were enrolled. 8 patients had grade 1 knee OA, 28 patients had grade 2 knee OA, 52 patients had grade 3 knee OA and 12 patients had grade 4 knee OA according to Kellgren - Lawrence system. The mean age was $61.25 \pm 8.71$ years. Of the total, 18 patients (18\%) were in the likely NP group; 23 patients (23\%) were in the possible NP group and 59 (59\%) patients were in the unlikely NP group according to PainDETECT scores. Sociodemographic characteristics of likely NP, possible NP, and unlikely NP groups are shown in Table 1. No statistical differences were detected between the groups in terms of sociodemographic data ( $p>0.05$ ).

On comparing the clinical parameters between the three groups; significant differences were detected in symptom duration, VAS, WOMAC, SF-36 physical functioning subscale, physical role functioning subscale, social role functioning subscale, vitality subscale, bodily pain subscale, general health perceptions subscale and HAM-D scores ( $p<0.05$ ). However, no significant differences were detected between groups for the results of SF-36 emotional role functioning and mental health subscales $(p>0.05)$. Data are reported in Table 2. 


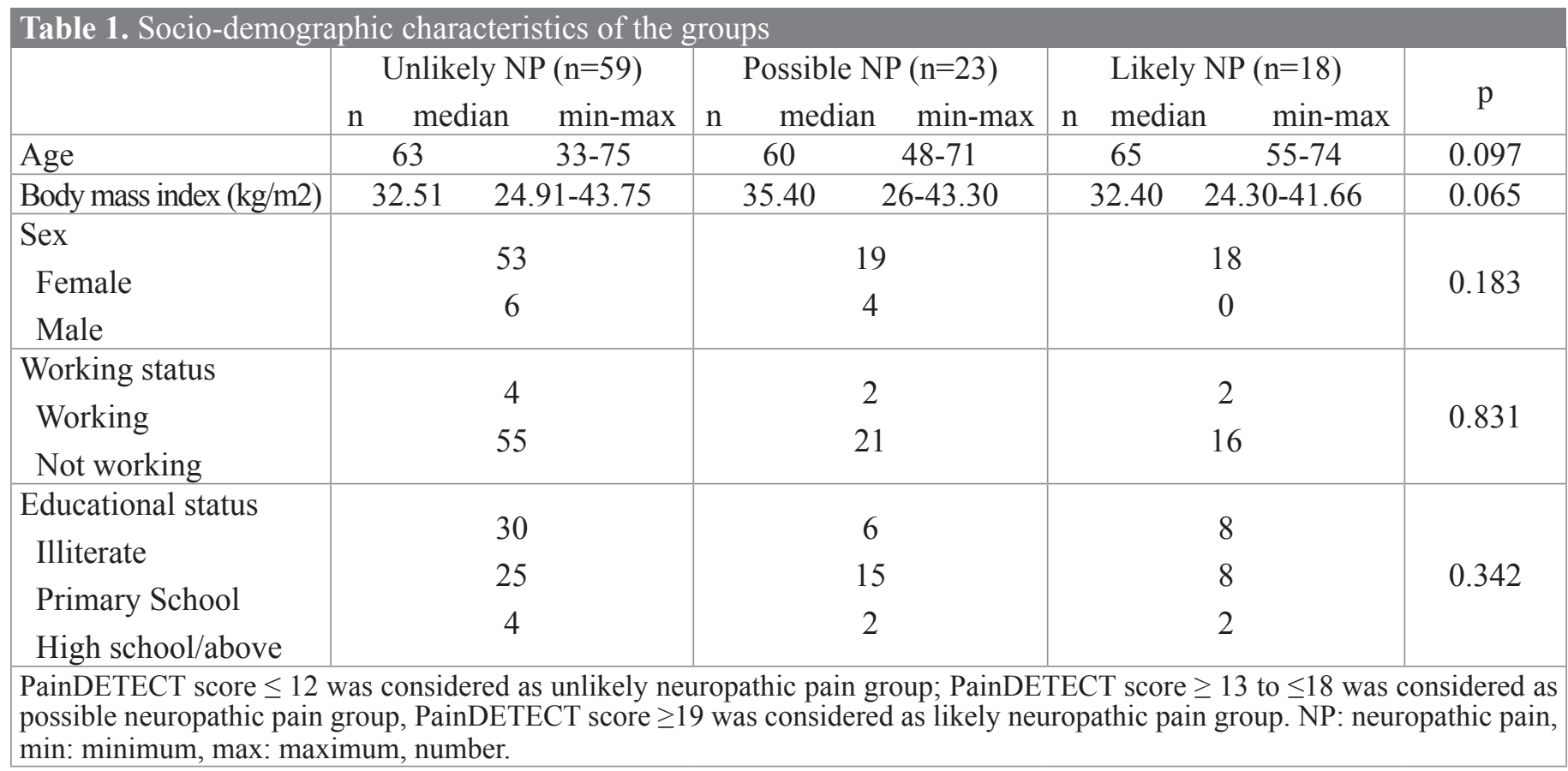

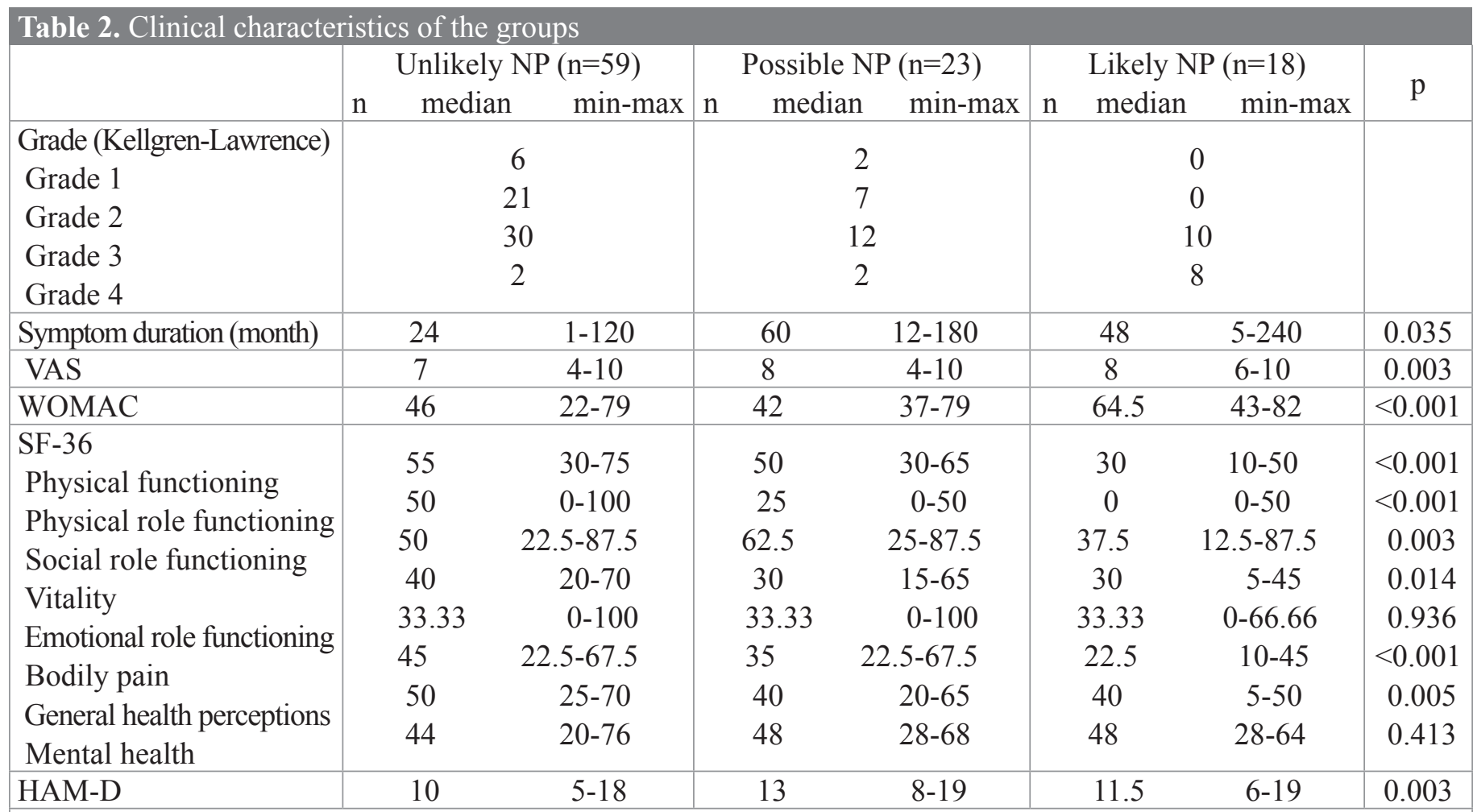

PainDETECT score $\leq 12$ was considered as unlikely neuropathic pain group; PainDETECT score $\geq 13$ to $\leq 18$ was considered as possible neuropathic pain group, PainDETECT score $\geq 19$ was considered as likely neuropathic pain group. NP: neuropathic pain, min: minimum, max: maximum. VAS: Visual Analog Scale, WOMAC: Western Ontario and McMaster Universities Osteoarthritis Index, SF-36: Short Form-36, HAM-D: Hamilton Depression Scale.

PainDETECT scores were significantly and positively correlated with VAS, WOMAC and HAM-D scores $(r=0.377, p<0.001$; $r=0.457, p<0.001 ; r=0.393, p<0.001$ and $r=0.380, p<$ 0.001 , respectively). Additionally, PainDETECT scores were significantly and negatively correlated with SF-36 physical functioning, physical role functioning, social role functioning, vitality, bodily pain, and general health perceptions subscales scores $(r=-0.572, p<0.001 ; r=-0.536, p<0.001 ; r=-0.267, p=$ $0.007 ; r=-0.362, p<0.001 ; r=-0.462, p<0.001$ and $r=-0.507$, $\mathrm{p}<0.001$, respectively) (Table 3 ). 


\begin{tabular}{l} 
Table 3. Correlation analysis between clinical \\
parameters and PainDETECT scores \\
\hline
\end{tabular}

VAS: Visual Analog Scale, WOMAC: Western Ontario and McMaster Universities

Osteoarthritis Index, SF-36: Short Form-36, HAM-D:

Hamilton Depression Scale.

Female sex and radiologic grade independently and significantly affect painDETECT scores according to the linear regression analysis $(p<0.05)$. However, age, body mass index, working status and symptom duration were not found to be associated with painDETECT scores ( $p>0.05)$ (Table 4).

\begin{tabular}{|l|c|c|c|l|}
\hline & & Table 4. Risk factors affecting PainDETECT scores \\
\hline & B & Sig. & \multicolumn{2}{|c|}{$\begin{array}{c}95.0 \% \\
\text { Confidence } \\
\text { interval for B }\end{array}$} \\
\cline { 3 - 5 } & & $\begin{array}{c}\text { Lower } \\
\text { Bound }\end{array}$ & $\begin{array}{l}\text { Upper } \\
\text { Bound }\end{array}$ \\
\hline Age & -0.27 & 0.739 & -0.189 & 0.134 \\
\hline Sex & -4.951 & 0.028 & -9.358 & -0.543 \\
\hline $\begin{array}{l}\text { Body mass index } \\
\text { (kg/m2) }\end{array}$ & 0.036 & 0.777 & -0.214 & 0.285 \\
\hline Working status & -0.611 & 0.811 & -5.663 & 4.441 \\
\hline Educational status & 0.764 & 0.485 & $-1,399$ & 2.928 \\
\hline Grade & 3.223 & 0.001 & 1.413 & 5.034 \\
\hline $\begin{array}{l}\text { Symptom duration } \\
\text { (month) }\end{array}$ & 0.019 & 0.201 & -0.10 & 0.47 \\
\hline
\end{tabular}

\section{Discussion}

In this research, the frequency of NP was investigated in patients with knee OA. We examined the effects of NP component on functional status, quality of life, perceived pain, and depression in knee OA. Additionally, we aimed to detect the factors associated with NP.

In our study, $18 \%$ of the patients had likely NP and $23 \%$ patients had possible NP. Conflicting results have been demonstrated in the literature about this issue. Soni et al. [19] reported that
\%8.6 of the knee OA patients had 13 or above PainDETECT score. Hochman et al. [20] found that NP components were present in $34 \%$ of the patients. In another study, 50\% of the knee OA patients were found to be in possible or likely NP groups [21]. In a systematic review, NP prevalence was calculated as $23 \%$ in knee or hip OA patients [22]. Differences in methodology, NP assessment tools, and sample sizes may influence the results of the above-mentioned studies. Additionally, differences in the patient characteristics such as average BMI level, radiologic grade, drug use, comorbidities, and disease duration may affect the results.

The etiopathogenesis of the NP in knee OA is still unclear. Although cartilage has an aneural and avascular structure; subchondral bone degeneration, periarticular soft tissue injury and inflammation may cause symptoms of NP by stimulating the peripheral nerves [4]. Peripheral and central sensitizations also play a role substantial role in this process. Similarities have been shown between the mediators in the etiology of NP and the mediators in the etiology of OA. The presence of local joint inflammation and affected cartilage and bone turnover in OA indicate a potential role of mediators in OA pain. The destruction of cartilage leads to secretion of cytokines and many other mediators from synovial cells. Mast cells, lymphocytes and macrophages secrete bradykinin and serotonin. Serotonin causes vasodilation and edema; bradykinin actives $C$ fibers. Additionally, bradykinin stimulates phospholipase A2 and cyclooxygenase which increase the levels of prostaglandins and leukotrienes. Prostaglandins cause secretion of substance $P$ from the peripheral sensitized nerves. The mediators and neuropeptides which are released from the knee may lead to peripheral sensitization. Therefore, low levels of stimulus are perceived as painful [23]. Continuous and intensive nociceptive inputs arising from the osteoarthritic knee may create variations in central pain processing and may cause central sensitization [5]. Lee et al. [24] reported that patients with OA are more susceptible to painful stimuli when compared to healthy controls. Neogi et al. [25] demonstrated a significant correlation between severity of symptoms and pressure pain sensitivity in knee OA.

We evaluated the link between NP component and functional status in patients with knee OA. Likely NP group has higher WOMAC total scores. PainDETECT scores were significantly and positively correlated with WOMAC total scores. Roubille et al. [21] found similar results in their research. Gölge et al. [26] 
determined higher WOMAC scores in NP group. From these results, we consider that NP component is associated with poor functionality and severe disability in knee OA. Additionally, we found that NP negatively affects the quality of life in knee OA. Garip et al. [27] evaluated 150 patients consisting of $\mathrm{OA}$, ankylosing spondylitis and rheumatoid arthritis in their study and significant correlations were detected between painDETECT scores and Nottingham Health profile. In another study, patients were divided into two groups (with NP and without NP) according to painDETECT scores [28]. There was a significant difference in SF-36 subscales between two groups and NP scores were significantly and negatively correlated with SF-36 subscales. In our study, a positive correlation was detected between painDETECT scores and HAM-D scores. In agreement with our result, Hochman et al. [29] reported a link between NP and depressive symptom score. In our study, a positive correlation was detected between painDETECT score and HAM-D score. Depression and other psychological disorders may induce central sensitization and NP. Psychological disorders might affect neural activity and perception of pain in $\mathrm{OA}$.

Risk factors associated with NP component in knee OA were also evaluated. Female gender and radiologic grade independently and significantly affect NP. Age, body mass index, working status and symptom duration were not found to be associated with painDETECT scores. Hochman et al. [20] evaluated NP in knee OA and compared patients in age, sex and educational status. Age was found to be significantly different in their study. Relationship was not observed between painDETECT scores and symptom duration, radiologic grade, and femoral cartilage thickness in another study [30]. Aşkın et al. [28] reported an association between radiologic grade and painDETECT score. At the onset of the OA, synovitis increases joint fluid, raises pressure and influences peripheral nerve endings. In high grade OA, decrease in joint fluid and degeneration in subchondral structure are observed. Deterioration of weight bearing surface in high grade OA leads to irritation of nerves which innervate the subchondral structure [31]. All of these mechanisms may contribute to the development of NP in late phase of knee OA.

Our study includes several limitations. Sample size is small. Most of the patients are female, vast majority of whom are not working. We did not assess healthy controls. NP was diagnosed solely using the PainDETECT questionnaire which is a self- reported scale. Patients were not evaluated with pressure pain threshold, sensory threshold for heat and cold and pinprick test. In conclusion, although pain in knee $O A$ is historically considered as nociceptive, some patients have neuropathic component. NP component is associated with higher levels of pain, reduced functionality, impairment in quality of life, higher depression scores and advanced radiologic grade. Neuropathic and nociceptive pain managements have different treatment choices. Treatment strategies focusing on the NP should be kept in mind while treating knee OA. We suggest studies involving larger sample sizes and quantitative measurements for a detailed evaluation of the neuropathic component of $O A$.

\section{Declaration of conflict of interest}

The authors received no financial support for the research and/or authorship of this article. There is no conflict of interest.

\section{References}

1. Loeser RF, Goldring SR, Scanzello CR, Goldring MB. Osteoarthritis: a disease of the joint as an organ. Arthritis Rheum 2012; 64: 1697-707.

2. Kawano MM, Araújo IL, Castro MC, Matos MA. Assessment of quality of life in patients with knee osteoarthritis. Acta Ortop Bras 2015; 23: 307-10.

3. Felson DT. The sources of pain in knee osteoarthritis. Curr Opin Rheumatol 2005; 17: 624-8.

4. Arendt-Nielsen L. Pain sensitisation in osteoarthritis. Clin Exp Rheumatol 2017; 107: 68-74.

5. Martindale JC, Wilson AW, Reeve AJ, Chessell IP, Headley PM. Chronic secondary hypersensitivity of dorsal horn neurons following inflammation of the knee joint. Pain 2007; 133: 79-86.

6. Suri S, Gill SE, Massena de Camin S, Wilson D, McWilliams DF, Walsh DA. Neurovascular invasion at the osteochondral junction and in osteophytes in osteoarthritis. Ann Rheum Dis 2007; 66: 1423-28.

7. Mease PJ, Hanna S, Frakes EP, Altman RD. Pain mechanisms in osteoarthritis: understanding the role of central pain and current approaches to its treatment. J Rheumatol 2011; 38: 1546-51.

8. Kidd B. Mechanisms of pain in osteoarthritis. HSS J 2012; 8: 26-28.

9. Ohtori S, Inoue G, Orita S, et al. Efficacy of combination of meloxicam and pregabalin for pain in knee osteoarthritis. Yonsei Med J 2013; 54: 1253-8. 
10. Kellgren JH, Lawrence JS. Radiological assessment of osteo-arthrosis. Ann Rheum Dis 1957; 16: 494-502.

11. McConnell S, Kolopack P, Davis AM. The Western Ontario and McMaster Universities Osteoarthritis Index (WOMAC): a review of its utility and measurement properties. Arthritis Rheum 2001; 45: 453-61.

12. Tüzün EH, Eker L, Aytar A, Dağkapan A, Bayramoğlu M. Acceptability, reliability, validity and responsiveness of the Turkish version of WOMAC osteoarthritis index. Osteoarthritis Cartilage 2005; 13: 28-33.

13. Hochman JR, Davis AM, Elkayam J, Gagliese L, Hawker GA. Neuropathic pain symptoms on the modified painDETECT correlate with signs of central sensitization in knee osteoarthritis. Osteoarthritis Cartilage 2013; 21: 1236-42.

14. Alkan H, Ardic F, Erdogan C, Sahin F, Sarsan A, Findikoglu $G$. Turkish version of the painDETECT questionnaire in the assessment of neuropathic pain: a validity and reliability study. Pain Med 2013; 14: 1933-43.

15. Pınar R. Reliability and construct validity of the SF-36 in Turkish cancer patients. Qual Life Res 2005; 14: 259-64.

16. Ware Jr JE, Sherbourne CD. The MOS 36-item short-form health survey (SF-36). I. Conceptual framework and item selection. Med Care 1992; 30: 473-83.

17. Akdemir A, Türkçapar MH, Orsel SD, Demirergi N, Dag I, Ozbay MH. Reliability and validity of the Turkish version of the Hamilton Depression Rating Scale. Compr Psychiatry 2001; 42: 161-65.

18. Hamilton M. A rating scale for depression. J Neurol Neurosurg Psychiatry 1960; 23: 56-62.

19. Soni A, Batra RN, Gwilym SE, et al. Neuropathic features of joint pain: a community-based study. Arthritis Rheum 2013; 65: 1942-9.

20. Hochman JR, French MR, Bermingham SL, Hawker GA. The nerve of osteoarthritis pain. Arthritis Care Res (Hoboken) 2010; 62: 1019-23.

21. Roubille C, Raynauld JP, Abram F, et al. The presence of meniscal lesions is a strong predictor of neuropathic pain in symptomatic knee osteoarthritis: a cross-sectional pilot study. Arthritis Res Ther 2014; 16: 507.
22. French HP, Smart KM, Doyle F. Prevalence of neuropathic pain in knee or hip osteoarthritis: A systematic review and meta-analysis. Semin Arthritis Rheum 2017; 47: 1-8.

23. Yücel A, Çimen A. Neuropathic pain: Mechanisms, diagnosis and treatment. 2005; 17: 5-13.

24. Lee YC, Lu B, Bathon JM, et al. Pain sensitivity and pain reactivity in osteoarthritis. Arthritis Care Res (Hoboken) 2011; 63: 320-7.

25. Neogi T, Frey-Law L, Scholz J, et al. Sensitivity and sensitisation in relation to pain severity in knee osteoarthritis: trait or state? Ann Rheum Dis 2015; 74: 6828.

26. Gölge UH, Şen HM, Kuyucu E, et al. Investigation of knee pain in osteoarthritic and neuropathic pain awareness. Acta Orthop Belg 2015; 81: 639-46.

27. Garip Y, Eser F, Kılıçarslan A, Bodur H. Prevalence of Neuropathic Pain in Rheumatic Disorders: Association with Disease Activity, Functional Status and Quality of Life. Arch Rheumatol 2015; 30: 231-7.

28. Aşkın A, Özkan A, Tosun A, Demirdal ÜS, İsnaç F. Quality of life and functional capacity are adversely affected in osteoarthritis patients with neuropathic pain. Kaohsiung J Med Sci 2017; 33:152-8.

29. Hochman JR, Gagliese L, Davis AM, Hawker GA. Neuropathic pain symptoms in a community knee OA cohort. Osteoarthritis Cartilage 2011; 19: 647-54.

30. Mesci N, Mesci E, Külcü DG. Association of neuropathic pain with ultrasonographic measurements of femoral cartilage thickness and clinical parameters in patients with knee osteoarthritis. J Phys Ther Sci 2016; 28: 2190-5.

31. Ohtori S, Orita S, Yamashita $M$, et al. Existence of a neuropathic pain component in patients with osteoarthritis of the knee. Yonsei Med J 2012; 53: 801-5. 